\title{
Differential gene expression in diapausing and active Calanus finmarchicus (Copepoda)
}

\author{
Ann M. Tarrant ${ }^{1, *, * *}$, Mark F. Baumgartner ${ }^{1, * *}$, Tim Verslycke ${ }^{1}$, \\ Catherine Lynn Johnson ${ }^{2}$
}

\author{
${ }^{1}$ Woods Hole Oceanographic Institution, 45 Water Street, Woods Hole, Massachusetts 02540, USA \\ ${ }^{2}$ Bedford Institute of Oceanography, 1 Challenger Drive, PO Box 1006, Dartmouth, Nova Scotia B2Y 4A2, Canada
}

\begin{abstract}
To survive long periods of low food availability, some calanoid copepods have a life history that includes a diapause phase during which copepodids delay development to adulthood, migrate to depth, reduce metabolism, and utilize stored lipids for nourishment. While seasonal patterns in diapause have been described, the environmental and physiological regulation of diapause has not been elucidated. We collected Calanus finmarchicus C5 copepodids from surface (0 to $39 \mathrm{~m})$ and deep (157 to $201 \mathrm{~m}$ ) waters in the Gulf of Maine, and both morphological and biochemical measurements indicated that these copepodids were from active and diapausing populations, respectively. Two complementary molecular techniques were used to compare gene expression in these 2 groups: (1) suppressive subtractive hybridization (SSH) was used to identify genes that may be differentially expressed, and (2) quantitative real-time RT-PCR was used to characterize patterns of gene expression in individual copepodids. Three genes associated with lipid synthesis, transport and storage (ELOV, FABP, RDH) were upregulated (more highly expressed) in active copepods, particularly those with small oil sacs. Expression of ferritin was greater in diapausing copepods with large oil sacs, consistent with a role of ferritin in chelating metals to protect cells from oxidative stress and/or delay development. Ecdysteroid receptor (EcR) expression was greater in diapausing copepods, highlighting the need for further investigation into endocrine regulation of copepod development. This study represents the first molecular characterization of gene expression associated with calanoid copepod diapause and provides a foundation for future investigations of the underlying mechanisms that regulate diapause.
\end{abstract}

KEY WORDS: Diapause $\cdot$ Copepod · Calanus finmarchicus $\cdot$ Subtractive hybridization · Gene expression · Gulf of Maine

\section{INTRODUCTION}

In pelagic ecosystems, energy captured during photosynthesis is made available to higher trophic levels by herbivorous zooplankton. Calanoid copepods, such as Calanus finmarchicus in the temperate North Atlantic, C. pacificus in the temperate North Pacific, and Neocalanus spp. in the sub-polar North Pacific, are key intermediaries in this process of trophic energy transfer. Many animals near the top of the food web depend on these copepods, either via direct predation (e.g. commercially-important fish, basking sharks, sea- birds, and some whales) or via trophic relationships (e.g. piscivorous predators that feed on bait fish such as herring or sand lance, which in turn feed on copepods). Some calanoid copepods can survive periods of low food abundance by undergoing an ontogenetic vertical migration to depth and entering a resting state referred to as diapause (Hirche 1996). Prior to entering diapause, lipids are sequestered in the form of wax esters in an oil sac (Miller et al. 1998, Lee et al. 2006) and used as an energy source for survival during the protracted period of starvation during dormancy and for reproduction after emergence from dormancy. As a 
result of this build-up of lipids, copepods with this life history strategy are an extremely nutritious food source for their predators. Thus, the environmental and physiological factors that control development and, in particular, diapause, have important implications for marine ecosystem processes.

The environmental signals and internal biological processes that regulate diapause in calanoid copepods are unknown, and experimental studies remain difficult because copepods do not reliably enter diapause in the laboratory. In the field, investigators have relied on a suite of behavioral, morphological, and biochemical characteristics to distinguish between diapausing and active copepodids. The hallmarks of diapause are a deep distribution (within 50 to $100 \mathrm{~m}$ of the bottom in neritic environments and below 200 to $300 \mathrm{~m}$ in oceanic waters (Sameoto \& Herman 1990, Miller et al. 1991, Dale et al. 1999, Heath et al. 2004), predominance of a single stage (Heath et al. 2004), torpor (Hirche 1983), empty guts with reduced epithelium (Hallberg \& Hirche 1980, Hirche 1983, Bonnet et al. 2007), low digestive enzyme activity (Tande \& Slagstad 1982, Hirche 1983, 1989), low respiration rates (Hirche 1983), and a large oil sac (Hirche 1983, Miller et al. 2000). Ecdysis (molting) is delayed during diapause, and copepodids remain predominantly in the postmolt phase of jaw (mandibular gnathobase) development and have low ecdysteroid concentrations (Miller et al. 1990, 1991, Johnson 2003, 2004). Other biochemical indicators associated with diapause include a low cellspecific RNA content (indicative of reduced transcriptional activity, Wagner et al. 1998, Wagner et al. 2001), and lower activity of aminoacyl-tRNA synthetases (indicative of reduced rates of protein synthesis, Yebra et al. 2006). These markers are particularly useful for distinguishing between active and diapausing copepods, but they remain frustratingly descriptive. Because the physiological processes associated with copepod ecdysis and diapause remain poorly understood, there are no available characteristics that can be used to predict the fate of a copepod, such as whether it will enter into or emerge from diapause.

As a result of the availability of sequenced genomes and related technical advances, molecular approaches have proven extremely useful in identifying the regulatory cascades associated with dormancy in other taxa, such as the dauer state in the nematode Caenorhabditis elegans (Wang \& Kim 2003, Liu et al. 2004) and larval and/or pupal diapause in homometabolous insects (Flannagan et al. 1998, Denlinger 2002, Hayward et al. 2005, Tachibana et al. 2005, Williams et al. 2006). Approaches to characterizing gene expression may prove particularly useful for studies of diapause, since characteristic patterns of gene expression should presage physiological changes associated with ecdysis and dormancy. While gene expression has begun to be characterized in other marine arthropods that have dormant phases (e.g. the encysted embryos of the brine shrimp Artemia franciscana; Chen et al. 2003), changes in gene expression associated with diapause have yet to be investigated in even the most well-studied of calanoid copepods.

Calanus finmarchicus appears to initiate diapause in both the shelf basins and oceanic waters of the North Atlantic. The life history of $C$. finmarchicus has been intensively studied, particularly during the recent investigations in the Gulf of Maine and Georges Bank region off the northeast United States as part of the US GLOBEC program (Wiebe et al. 2001). In the Gulf of Maine, C. finmarchicus emerge from diapause during early winter and molt into adults (Durbin et al. 1997, Durbin et al. 2000) (Fig. 1). Males emerge first followed later by females (Durbin et al. 2000), and the adults may mate as they migrate to the surface (as in C. marshallae, Tsuda \& Miller 1998). Females begin producing eggs at rates of up to 50-70 eggs d ${ }^{-1}$ (Campbell et al. 2001). The early naupliar stages (N1-2) do not feed, but the later naupliar stages (N3-6), all copepodid stages (C1-5), and the adults feed primarily on phytoplankton (although omnivory has been observed: Ohman \& Runge 1994, Basedow \& Tande 2006). During the later copepodid stages, C. finmarchicus develops an oil sac, and by stage $C 5$, this oil sac has reached its maximum size, comprising up to $50 \%$ of body volume (Miller et al. 2000). After reaching the C5 stage, a portion of the population migrates to depth and initiates diapause; however, the remaining C5 copepodids molt into adults, reproduce, and spawn another generation. Two or more generations per year are likely in Gulf of Maine waters (Meise \& O'Reilly 1996, Durbin et al. 1997, 2000, Miller et al. 2000).

In the present study, Calanus finmarchicus C5 copepodids were collected from the Gulf of Maine, and several morphological and biochemical criteria indicated the presence of a surface active population and a deep diapausing population. Two complementary molecular techniques were used to investigate differential gene expression in these 2 populations. (1) Suppressive subtractive hybridization ( $\mathrm{SSH}$ ) was used to identify genes likely to be differentially expressed between diapausing and active C5 copepodids. (2) Expression of a subset of genes was characterized in individual diapausing and active copepodids by quantitative real-time RT-PCR. To our knowledge, this study represents the first application of molecular techniques to the characterization of diapause in calanoid copepods, and provides a foundation for future investigations of the underlying mechanisms that regulate diapause. 


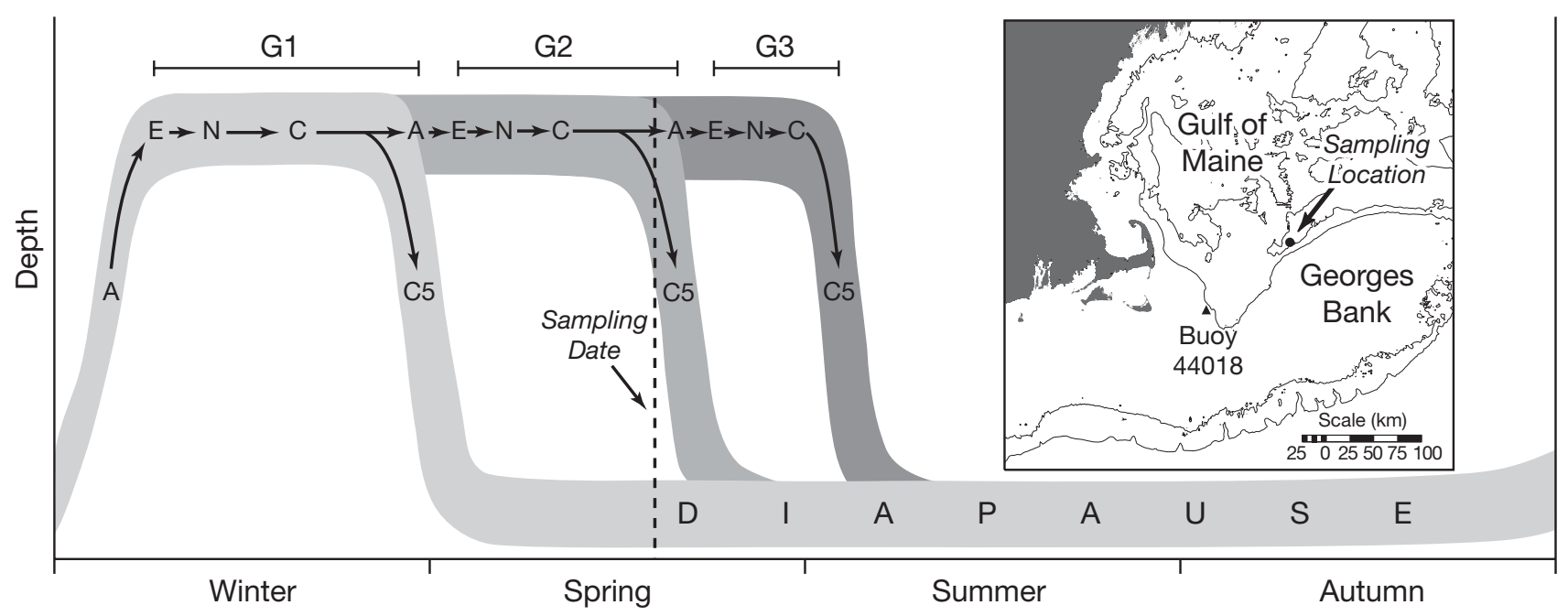

Fig. 1. Calanus finmarchicus. Seasonal population development and depth distribution of 3 generations (G1, G2, and G3) in the Gulf of Maine. Adults (A) ascend from depth in early winter and spawn eggs (E), which develop through naupliar (N) and copepodid (C) stages. Some C5 copepodids undertake an ontogenetic vertical migration to depth and enter diapause, while others molt into adults to spawn subsequent generations. Dashed line: sampling date (May 16, 2005); sampling location shown on inset map. The $91.4 \mathrm{~m}$ (50 fathom) and $200 \mathrm{~m}$ isobaths are also shown

\section{MATERIALS AND METHODS}

Sampling. Copepods were collected at a station in Franklin Basin just to the north of Georges Bank, USA (Fig. 1), on 16 May 2005 between 15:30 and 16:15 h local time during a cruise aboard the NOAA Ship 'Albatross $I V$ '. We used a $0.25 \mathrm{~m}^{2}$ multiple openingclosing net and environmental sensing system (MOCNESS, Wiebe et al. 1976) outfitted with $150 \mu \mathrm{m}$ mesh nets to collect zooplankton samples in 2 depth strata: 157 to $201 \mathrm{~m}$ and 0 to $39 \mathrm{~m}$ (hereafter referred to as the deep and shallow samples, respectively). Water depth at this station was $215 \mathrm{~m}$. Upon recovery of the MOCNESS, water was immediately poured from the codend buckets of the deep and shallow nets into separate ice-chilled containers and then transported to the ship's wet laboratory. The containers were kept in a closed ice chest, and subsamples were periodically transferred from these containers to Petri dishes to capture individual, live, Calanus finmarchicus C5 copepodids using a wide-bore glass Pasteur pipette. Copepodids were mounted on a depression slide, photographed, and then individually preserved in microcentrifuge tubes with RNAlater (Ambion). Observations of gut contents or fecal-pellet production were noted while viewing the live animals. Photographs of single animals were taken at 50× magnification with a Nikon Coolpix 5000 digital camera mounted on a Wild M5 microscope, and all measurements were calibrated with digital photographs of a stage micrometer taken just prior to sampling. Bulk samples of several hundred copepods from each of the shallow and deep nets were also preserved in RNAlater in the field, and C. finmarchicus C5 copepodids were isolated from these samples several weeks after the cruise. The remaining net samples were preserved in a $5 \%$ borate-buffered formalin and seawater solution, and later enumerated by sorting, identifying, and counting all taxa in subsamples drawn with a Hensen stempel pipette. Subsample volumes were obtained such that 100 or more of the most abundant copepod species were counted. All later (C4-C6) C. finmarchicus stages were enumerated separately.

Morphometrics. The length, width, oil sac volume, and fractional fullness of each copepodid were estimated from the digital photographs using custom software written in IDL (ITT Visual Information Solutions). Each photograph was rotated and, if necessary, reflected so that animals were in a standard orientation (head pointing to the left, legs pointing down). Length was measured from the head to the posterior tip of the last prosome segment. Oil sac volume was estimated using methods similar to Miller et al. (2000). The oil sac was initially considered to be a cylinder with varying height, so that any dorsal-ventral cross section is circular. An outline of the oil sac was created as a closed polygon typically consisting of 165 to 260 connected points. The volume of each unit (i.e. dorsal-ventral circular cross-section) of the oil sac along the anteriorposterior axis was then estimated as the product of the unit width and the area of the cross-section $(\mathrm{W} \times$ $0.25 \pi \mathrm{H}^{2}$, where $\mathrm{W}$ is the unit width and $\mathrm{H}$ is the height 
of the oil sac outline). The total oil sac volume was estimated by summing all of the unit cylindrical cross sections. The unit width was the calibrated width of one digital pixel $(4.545 \mu \mathrm{m})$. Miller et al. (2000) found that the oil sac is not always symmetric when viewed dorsally (i.e. it is not a perfect cylinder, particularly for animals with larger oil sacs), therefore the estimates of oil sac volume from our lateral photographs were adjusted using the empirical cubic polynomial of Miller et al. (2000; see their Fig. 2). Finally, larger copepodids have the capacity to store disproportionately more oil; to account for this, we expressed the fullness of oil sacs as a fraction of the apparent maximum capacity estimated by Miller et al. (2000) (apparent maximum $=0.5822 \mathrm{~mm}^{2} \times$ Length $-1.0208 \mathrm{~mm}^{3}$ ). Fractional fullness, therefore, is a measure of oil sac size that is independent of the size of the copepodid.

RNA to DNA ratios. RNA and DNA content were quantified in randomly-selected individual C5 copepodids ( $\mathrm{n}=15$ shallow, 15 deep; Table 1) using methods described by Wagner et al. $(1998,2001)$ that were modified slightly to use SYBR green (Invitrogen) in place of ethidium bromide. Briefly, nucleic acids were extracted by vigorous shaking in a $1 \%$ sarcosyl buffer. Dilutions of yeast RNA (Ambion) and calf thymus DNA (Sigma) were used as standards. To quantify total nucleic acids, aliquots of the diluted copepod extracts and standards were incubated with SYBR green (1:2500 assay concentration) in a 96-well flat-bottomed plate. The plates were shaken at room temperature for $15 \mathrm{~min}$, and fluorescence was measured using a Cytofluor 4000 fluorometer with $485 \mathrm{~nm}$ (excitation) and $530 \mathrm{~nm}$ (emission) filters. The samples were then digested with RNase and scanned a second time. DNA concentrations were calculated using the results from the second scan, and RNA concentrations were calculated from the difference in fluorescence between the

Table 1. Calanus finmarchicus. Source and sample sizes for each analysis. Bulk: bulk samples taken from the deep and shallow nets, preserved en masse in RNAlater, and later sorted to isolate C5 copepodids; Ind: C5 copepodids that were live-sorted, photographed, and individually preserved in RNAlater. Morphometric data were collected from digital photographs of the same individual copepodids used in the qPCR and RNA:DNA analyses

\begin{tabular}{|lcrrr|}
\hline \multirow{2}{*}{ Analysis } & \multirow{2}{*}{ Sample } & \multicolumn{3}{c|}{ Sample size } \\
\cline { 3 - 5 } & & Shallow & Deep & Total \\
\hline SSH & Bulk & 50 & 50 & 100 \\
Preliminary screening & Ind & 5 & 5 & 10 \\
qPCR & Ind & 21 & 21 & 42 \\
RNA:DNA & Ind & 15 & 15 & 30 \\
Morphometrics & Ind & 36 & 36 & 72 \\
\hline
\end{tabular}

first and second scans. RNA to DNA ratios were logtransformed for statistical analysis and are hereafter referred to as RNA:DNA.

RNA extraction for gene expression analyses. Total RNA was extracted from pooled or individual C5 copepodids using the Aurum Total RNA Mini Kit (Bio-Rad) with slight modification. C5 copepodids were removed from RNAlater with a spatula and homogenized in $1 \mathrm{ml}$ RNA STAT-60 (Tel-Test) using a teflon homogenizer. The homogenate was mixed with $200 \mu$ l of chloroform and centrifuged at $12000 \times \mathrm{g}$ for $15 \mathrm{~min}$ at $4^{\circ} \mathrm{C}$. The upper aqueous phase was added to the Aurum Total RNA Mini Kit column and processed according to the manufacturer's protocol, including on-column DNase digestion. RNA yield and purity was quantified using a ND-1000 spectrophotometer (Nanodrop). RNA quality was visualized for pooled samples and selected individual samples on a denaturing agarose gel.

Suppressive subtractive hybridization (SSH). Using the method described in the above section, total RNA was extracted from 2 pooled samples drawn from the sorted bulk samples: (1) 50 deep C5 copepodids and (2) 50 shallow C5 copepodids (Table 1). Double-stranded complementary DNA (cDNA) was synthesized from $1 \mu \mathrm{g}$ of each of these 2 RNA samples using the BD Atlas SMART Fluorescent Probe Amplification Kit (Clontech) without incorporation of fluorescent nucleotides. The cDNAs were digested, adapter-ligated, hybridized, and amplified using the PCR-select cDNA Subtraction Kit (Clontech) according to the manufacturer's protocols. To facilitate cloning, PCR products were incubated with dATP and Taq polymerase (Promega) for $30 \mathrm{~min}$ at $70^{\circ} \mathrm{C}$ (A-tailing). Products were cloned into the pGEM-T Easy vector (Promega). Two subtractive libraries were constructed with deep and shallow samples alternately serving as 'tester' and 'driver'. Clones from both libraries were sequenced at the Josephine Bay Paul Center Sequencing Facility (Marine Biological Laboratory, Woods Hole, MA). Sequences were trimmed using Bioedit (Jakobsson et al. 2006) and compared with the NCBI database using the blastn and blastx algorithms.

Quantitative real-time reverse-transcription polymerase chain reaction (qPCR). Assays were designed to measure the expression of (1) genes of interest,

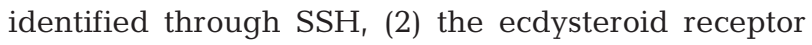
(EcR), and (3) candidate housekeeping genes. Seven genes were selected from the $\mathrm{SSH}$ libraries based on their known or hypothesized involvement in lipid metabolism, environmental sensing, hormonal signaling, molting, or diapause. The Calanus finmarchicus EcR sequence was provided by Henderson and colleagues (R. Henderson pers. comm.), and we subsequently cloned and sequenced a portion of this gene (GenBank accession number EF583877). Sequences of 
candidate housekeeping genes were detected in the background of the SSH libraries. Specific primers for qPCR reactions were designed against cloned sequences to target 75 to $150 \mathrm{bp}$ amplicons. Primers for one of the genes (actin) were targeted toward a previously published sequence (Crawford 1995, Accession number U21222), rather than the fragments sequenced from our libraries.

Total RNA was extracted from individual deep and shallow C5 copepodids as described above. Synthesis of cDNA was conducted using up to $300 \mathrm{ng}$ of total RNA (mean $=281 \mathrm{ng}$; for some dilute RNA samples, $<300 \mathrm{ng}$ were used) in a $30 \mu \mathrm{l}$ reaction with the iScript cDNA Synthesis Kit (Bio-Rad). qPCR was performed using the iQ SYBR Green Supermix (Bio-Rad), and reactions were run in an iCycler iQ Real-Time PCR detection system (Bio-Rad). For each gene, all samples were run in duplicate wells (technical replicates) on a single plate. The PCR mixture consisted of $11 \mu \mathrm{l}$ molecular biology grade distilled water, $12.5 \mu \mathrm{lQ}$ SYBR Green Supermix, $0.25 \mu \mathrm{l} 5$ '-primer $(10 \mu \mathrm{M}), 0.25 \mu \mathrm{l} 3^{\prime}$ primer $(10 \mu \mathrm{M})$, and $1 \mu \mathrm{l}$ cDNA. The PCR conditions were as follows: $95^{\circ} \mathrm{C}$ for $3 \mathrm{~min} ; 40$ cycles of $95^{\circ} \mathrm{C}$ for $15 \mathrm{~s}$ and $66^{\circ} \mathrm{C}$ for $45 \mathrm{~s}$ (the annealing temperature for the EcR assay was reduced to $62.1^{\circ} \mathrm{C}$ ). After 40 cycles, the PCR products from each reaction were subjected to melt-curve analysis to ensure that only a single product was amplified. Selected products were also visualized on $15 \%$ TBE gels and consistently yielded single bands.

Gene expression was first measured via $\mathrm{qPCR}$ in a set of cDNA samples $(n=5$ shallow and 5 deep C5 copepodids; Table 1) to screen candidate genes identified in the $\mathrm{SSH}$ analysis and to evaluate potential 'housekeeping genes'. Since SSH can produce false positives, this preliminary analysis was conducted to select genes that were most likely to be differentially expressed in the shallow and deep samples. For selected genes, expression was subsequently quantified via qPCR in cDNAs from 21 deep and 21 shallow C5 copepodids (Table 1).

Normalization of gene expression data. Measurements of transcript expression produced by qPCR can be normalized and reported in several ways. (1) A common approach is to normalize the expression of a gene of interest to expression of a constitutively expressed housekeeping gene to correct for variation in the starting cDNA template. This approach requires that the housekeeping gene be expressed at constant levels across the samples being analyzed. Expression of structural, metabolic and ribosomal genes (e.g. actin, glyceraldehyde 3-phosphate dehydrogenase and 16S ribosomal RNA) are commonly used to normalize qPCR data, but expression of these genes varies in many experimental systems, introducing an addi- tional source of error (Tricarico et al. 2002, Filby \& Tyler 2007, Sellars et al. 2007). (2) With 'absolute quantification' a standard curve is constructed using a serially diluted plasmid corresponding to the gene of interest, and detection of the amplified standards is used to calculate the number of transcripts of a gene of interest (Sellars et al. 2007). This approach assumes that the amplification efficiency is the same in the standards and unknown samples. (3) Another approach is to normalize samples to the starting amounts of total RNA or cDNA (Tricarico et al. 2002). With this approach, a 'relative standard curve' can be constructed using serially diluted cDNA to monitor amplification efficiency and inter-assay variability.

In the present study, we chose the third approach and normalized transcript expression to total RNA. To create a relative standard curve, cDNA was synthesized from $1.5 \mu \mathrm{g}$ of total RNA from the shallow pooled sample (also used in $\mathrm{SSH}$ ). This cDNA was then serially diluted and used with each qPCR assay to monitor amplification efficiency. Relative transcript expression was calculated by comparison of threshold cycles $\left(2^{-\Delta \mathrm{Ct}}\right)$. Threshold cycle values $\left(\mathrm{C}_{t}\right)$ for duplicate wells were averaged. The $\mathrm{C}_{t}$ of the undiluted pooled sample was subtracted from the $\mathrm{C}_{\mathrm{t}}$ of each individual sample, giving $\Delta \mathrm{C}_{\mathrm{t}}$. Because the amplification efficiency in each assay was near $100 \%, 2^{-\Delta C t}$ was used to calculate the abundance of transcript in the samples relative to the undiluted pooled sample. Samples were normalized by the amount of RNA used to prepare the cDNA and log-transformed for statistical analysis.

We also measured expression of 3 commonly-used housekeeping genes (glyceraldehyde 3-phosphate dehydrogenase, actin, and $16 \mathrm{~S}$ ribosomal RNA) to evaluate their use in future studies. Expression of these genes was used to identify outliers but was not used to normalize the data.

Analysis. Two-sample $t$-tests were used to examine differences between the deep and the shallow copepodids in the morphometric, RNA:DNA, and qPCRmeasured gene expression data. The $t$-tests for the morphometric and RNA:DNA data confirmed our assumption that the deep copepods were in diapause and the shallow ones were active. The analysis of the EcR data was designed to test the hypothesis that EcR expression varied between diapausing and active animals. For those genes identified by the SSH, however, the $t$-tests were not intended to address specific hypotheses about gene expression, but to confirm the results of the $\mathrm{SSH}$. Relationships between gene expression and the morphometric data were examined with correlation analysis, and patterns of gene expression were investigated using principal components analysis (PCA). 


\section{RESULTS}

\section{Outliers}

Several individual Calanus finmarchicus C5 copepodids $(n=8)$ had degraded oil sacs when photographed; therefore oil sac volumes were impossible to estimate (oil sacs appear to begin degrading prior to death). These individuals were excluded from the analyses. Scatterplots (not shown) of all morphological, RNA: DNA, and gene-expression data were used to identify outliers, and 5 more copepodids were excluded from further analysis: 2 had prosome lengths $>3 \mathrm{~mm}$ (likely Calanus glacialis), and 3 had very low expression of the housekeeping genes, actin and 16S rRNA, likely caused by RNA degradation.

\section{Morphometrics, physiology, and stage distributions}

There were significant differences between the deep and shallow copepodids in length, width, oil sac volume, fractional fullness, RNA:DNA (2-sample $t$-tests, $\mathrm{p}<$ 0.0001), and gut contents (Fig. 2). On average, copepodids from the deep sample were longer and wider, and had larger oil sacs (both in absolute volume and fractional fullness), lower RNA:DNA, and empty guts. There was much less variability in width, oil sac volume, and fractional fullness in the deep copepodids (Fig. 2b,c,d).
The vast majority of surface copepodids had food in their guts, indicating recent feeding activity, whereas most deep copepodids had empty guts (Fig. 2f). There was one extreme case in the RNA:DNA results from the deep sample in which the RNA and DNA contents were equal (Fig. 2e); however, none of the reported statistics, results, or conclusions change with the omission of this case. Late-stage copepodids (C4 to $\mathrm{C} 6$ ) in the shallow sample were $>3$ times more abundant and had a wider stage distribution (26.2 copepods $\mathrm{m}^{-3}$; $\mathrm{C} 4: 26 \%, \mathrm{C} 5: 43 \%, \mathrm{C} 6$ female: $25 \%$, and C6 male: $6 \%$ ) than in the deep sample ( 7.8 copepods $\mathrm{m}^{-3}$; C4: 0\%, C5: $67 \%$, C6 female: $22 \%$, and C6 male: $11 \%$ ). The shallow sample also contained eggs, nauplii, and C1 to C3 copepodid stages (albeit not sampled quantitatively by the $150 \mu \mathrm{m}$ mesh nets), whereas the deep sample contained only C5 copepodids and adults.

\section{SSH analysis}

Two SSH libraries were constructed (i.e. forwardand reverse-subtracted), and were targeted toward genes upregulated (more highly expressed) in surface(shallow library) and deep-collected (deep library) C5 copepodids. We single-pass sequenced 480 haphazardly-selected clones, which resulted in 368 sequences longer than $100 \mathrm{bp}$, after trimming of adaptor and vector sequences (Table 2). One 96-well plate of sequenc-
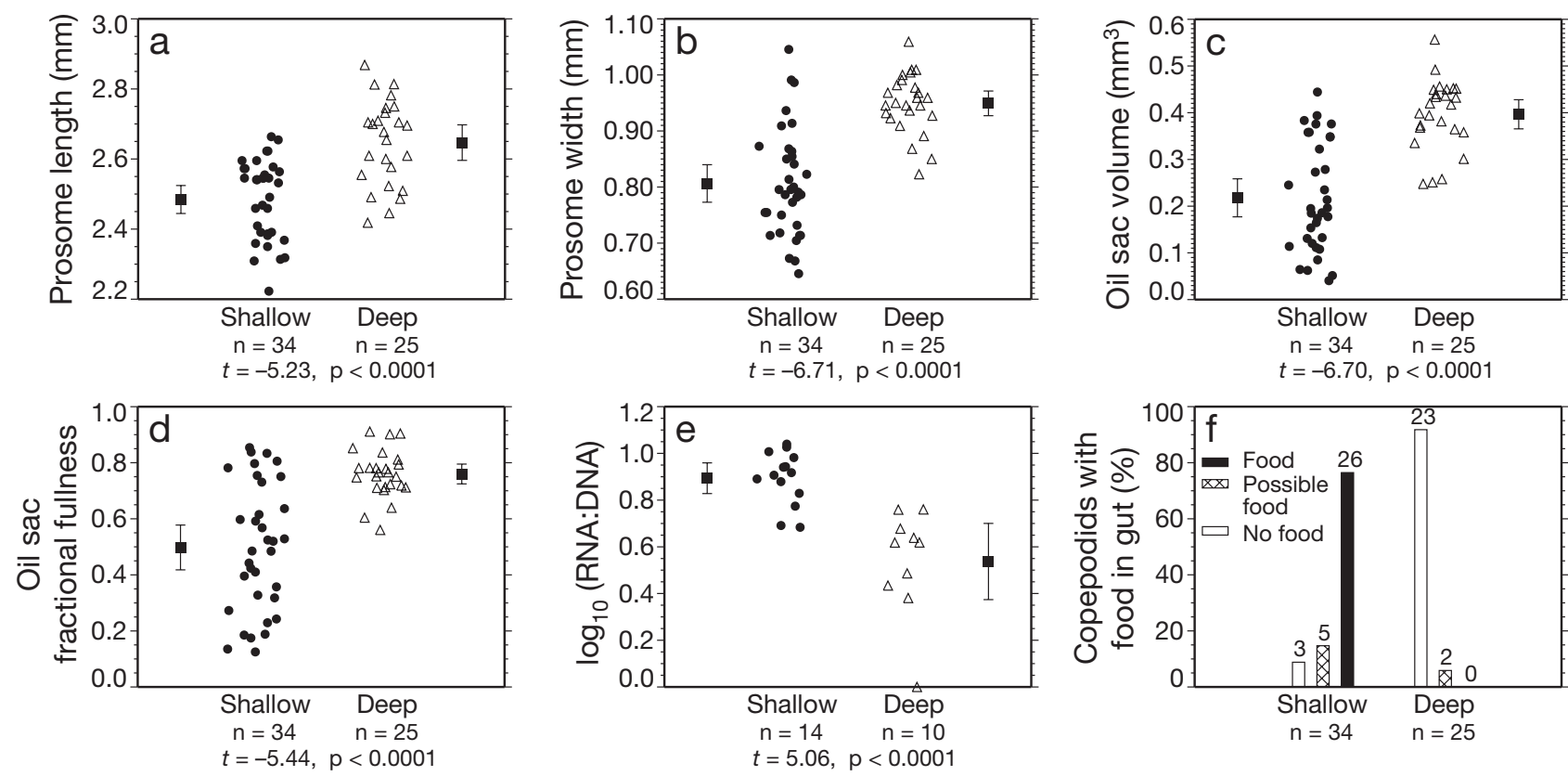

Fig. 2. Calanus finmarchicus. (a-e) Jitter plots of morphometric and RNA:DNA data for shallow ( $)$ and deep $(\Delta)$ copepodids. Each circle/triangle represents a single C5 copepodid (abscissa is a random offset); $\mathbf{\square}$ : mean $\pm 95 \%$ CI of the shallow (left) and deep (right) samples. Results of 2-sample t-test shown below panels. (f) Percentage of copepodids with either food in the gut or a fecal pellet present in the lower intestinal tract (numbers above bars indicate numbers of copepodids) 
Table 2. Calanus finmarchicus. General characteristics of C5 copepodid ESTs (expressed sequence tags) from suppressive subtractive hybridization. All identified genes with $\geq 3$ ESTs are indicated

\begin{tabular}{|lrrr|}
\hline & Shallow & Deep & Total \\
\hline Total & 173 & 195 & 368 \\
Ribosomal RNAs & 36 & 30 & 66 \\
Putative mRNAs & 137 & 165 & 302 \\
Unidentified & 80 & 111 & 191 \\
Identified mRNAs & 57 & 54 & 111 \\
Myosin & 10 & 26 & 36 \\
Troponin & 3 & 2 & 5 \\
Actin & 4 & 0 & 4 \\
Ferritin & 0 & 4 & 4 \\
BCS-1 & 0 & 3 & 3 \\
Cytochrome $c$ oxidase & 2 & 1 & 3 \\
Other $(\leq 2$ ESTs $)$ & 38 & 18 & 56 \\
\hline
\end{tabular}

ing reactions had a low template concentration and generated only 43 sequences that were $>100 \mathrm{bp}$. The remaining 384 clones resulted in 325 sequences. Of the 368 sequences, 66 were ribosomal; the remaining 302 expressed sequence tags (ESTs) have been deposited in the NCBI trace archive (GenBank accession numbers ES387147-448; dbEST identification numbers 46443277-578). Of the 302 ESTs, about a third could be identified $\left(E-\right.$ values $\left.<10^{-9}\right)$, including matches to uncharacterized predicted genes. Of the 111 identified ESTs, 55 represented myosin, troponin, actin, ferritin, BCS-1 (a gene identified in barnacle cyprid larvae, Okazaki \& Shizuri 2000), and cytochrome $c$ oxidase. Some of these may represent highly abundant genes not fully suppressed during the creation of subtractive libraries. Because our libraries were not screened prior to sequencing (e.g. by differential display), they are expected to include genes that are not truly differentially expressed (i.e. false positives).

From the SSH-derived sequences, 7 genes were selected for additional screening (Table 3). These genes were named based on sequence similarity to annotated genes in the NCBI database: (1) ELOV (elongation of very long chain fatty acids) is a member of a family of enzymes that facilitate the regulatory step in fatty acid elongation in both animals and plants (Jakobsson et al. 2006). (2) FABP (fatty acid binding protein) is related to cytosolic fatty acid and retinoid binding proteins. (3) $\mathrm{RDH}$ (reductase/dehydrogenase) is most similar to short chain dehydrogenases. (4) XAD (xanthine dehydrogenase) catalyzes the degradation of hypoxanthine and xanthine to uric acid. (5) BCS-2 (Barnacle cyprid specific gene 2) is a gene specific to the cyprid stage of the barnacle Balanus amphitrite (Okazaki \& Shizuri 2000); other similar proteins include hemebinding proteins, such as the 'SOUL' protein that is

Table 3. Calanus finmarchicus. Comparison of ESTs chosen for characterization by qPCR with closest reference sequences. Where 2 reference sequences are given, the 1 st sequence is a predicted protein with no additional annotation; the 2nd is the best hit with an annotated gene name. The E-value indicates the probability that another alignment would be more similar than the given alignment due to chance. Also shown is the ratio of amino acids shared between the EST and the reference sequence to the total number of amino acids in the reference sequence (\% amino acid identity in parentheses)

\begin{tabular}{|c|c|c|c|c|c|c|}
\hline $\begin{array}{l}\text { GenBank } \\
\text { accession } \\
\text { no. }\end{array}$ & $\begin{array}{l}\text { Abbreviation } \\
\text { (gene name) }\end{array}$ & $\begin{array}{l}\text { Reference species } \\
\text { (accession no.) }\end{array}$ & $\begin{array}{c}\text { Library } \\
\text { (no. of ESTs) }\end{array}$ & $\begin{array}{l}\text { EST } \\
\text { length } \\
\text { (bp) }\end{array}$ & E-value & $\begin{array}{l}\text { EST/ref. } \\
\text { amino acid } \\
\text { identity } \\
\text { (\% identity) }\end{array}$ \\
\hline ES387246 & $\begin{array}{l}\text { ELOV (elongation } \\
\text { of very long chain } \\
\text { fatty acids; elongase) }\end{array}$ & $\begin{array}{l}\text { Tribolium castaneum } \\
(\mathrm{XP971544)} ; \\
\text { Aedes aegypti } \\
\text { (ABF18019) }\end{array}$ & Shallow (1) & 819 & $\begin{array}{l}6 \times 10^{-53} \\
2 \times 10^{-50}\end{array}$ & $\begin{array}{l}92 / 195 \\
(47) \\
91 / 191 \\
(47)\end{array}$ \\
\hline ES387222 & $\begin{array}{l}\text { FABP ( } \underline{\text { fatty }} \text { acid } \\
\text { binding protein) }\end{array}$ & $\begin{array}{l}\text { Tyrophagus putrescentiae } \\
\text { (AAU11502) }\end{array}$ & Shallow (1) & 537 & $3 \times 10^{-22}$ & $\begin{array}{c}58 / 134 \\
(43)\end{array}$ \\
\hline ES387201 & $\begin{array}{l}\text { RDH (reductase/ } \\
\text { dehydrogenase) }\end{array}$ & $\begin{array}{l}\text { Aedes aegypti } \\
\text { (EAT35430) }\end{array}$ & Shallow (1) & 364 & $1 \times 10^{-13}$ & $\begin{array}{c}29 / 70 \\
(41)\end{array}$ \\
\hline ES387254 & $\begin{array}{l}\text { XAD (xanthine } \\
\text { dehydrogenase) }\end{array}$ & $\begin{array}{l}\text { Gallus gallus } \\
\text { (NP990458) }\end{array}$ & Shallow (1) & 390 & $9 \times 10^{-21}$ & $\begin{array}{c}49 / 80 \\
(61)\end{array}$ \\
\hline ES387147 & $\begin{array}{l}\text { BCS2 (barnacle cyprid } \\
\text { specific gene } \underline{2})\end{array}$ & $\begin{array}{l}\text { Balanus amphitrite } \\
\text { (BAA99544) }\end{array}$ & Shallow (1) & 503 & $4 \times 10^{-20}$ & $\begin{array}{c}63 / 153 \\
(41)\end{array}$ \\
\hline ES387261 & $\begin{array}{l}\text { NCS (neuronal calcium } \\
\text { sensor; hippocalcin) }\end{array}$ & $\begin{array}{l}\text { Tribolium castaneum } \\
\text { (XP969439); } \\
\text { Caenorhabditus elegans } \\
\text { (NP492651) }\end{array}$ & Shallow (1) & 395 & $\begin{array}{l}1 \times 10^{-31} \\
3 \times 10^{-28}\end{array}$ & $\begin{array}{l}61 / 100 \\
(61) \\
55 / 100 \\
(55)\end{array}$ \\
\hline ES387446 & Ferritin & $\begin{array}{l}\text { Litopenaeus vannamei } \\
\text { (AAX55641) }\end{array}$ & Deep (4) & 600 & $9 \times 10^{-57}$ & $\begin{array}{c}110 / 169 \\
(65)\end{array}$ \\
\hline
\end{tabular}


strongly expressed in the chicken retina and pineal gland (Zylka \& Reppert 1999). (6) NCS (neuronal calcium sensor/hippocalcin) is a member of a family of calcium binding proteins that are primarily expressed in photoreceptor cells and neurons (Burgoyne 2004). (7) Ferritin is an iron-binding protein that is highly expressed in encysted embryos of the brine shrimp Artemia franciscana (Chen et al. 2003). Based on the $\mathrm{SSH}$ analysis, ferritin was predicted to be upregulated in deep copepodids, and all the other genes were predicted to be upregulated in shallow copepodids.

\section{qPCR analysis}

Oligonucleotide primers were designed (Table 4) and qPCR assays were developed for 11 genes (ELOV, FABP, RDH, XAD, BCS-2, NCS, ferritin, EcR, 16S, actin, and GAPDH). Among these, ELOV, FABP, RDH, XAD, BCS-2, NCS and ferritin were selected from the SSH results as candidate differentially-expressed genes. The preliminary screening for false positives indicated that XAD, BCS-2 and NCS showed little or no differences in expression between shallow and deep samples, and were not investigated further (data not shown). The EcR was selected a priori for measurement as a gene likely to regulate life history transitions (e.g. molting, reproduction and, potentially, diapause)

Table 4. Calanus finmarchicus. Sequences of oligonucleotide primers used in qPCR assays

\begin{tabular}{|c|c|}
\hline Gene & Primer sequences \\
\hline ELOV & $\begin{array}{l}\text { F: 5'-GTCTGGTGGTGTTTCTTCTCC-3' } \\
\text { R: 5'-CACATGCAGAGAGGTAAGTTGG-3' }\end{array}$ \\
\hline FABP & $\begin{array}{l}\text { F: 5'-GGTCATTGTCATGGTCAAACC-3' } \\
\text { R: 5'-CCAACCAGAAGGCTGTCAAG-3' }\end{array}$ \\
\hline $\mathrm{RDH}$ & $\begin{array}{l}\text { F: 5'-CTAGCCAGGTTGCTGATGAAG-3' } \\
\text { R: 5'-TCTTGGAGATGGTGAGGTCTG-3' }\end{array}$ \\
\hline $\mathrm{XAD}$ & $\begin{array}{l}\text { F: 5'-TGCTGCTTCAGTCTTCTTTGC-3' } \\
\text { R: 5'-CGAATTCTTTCTGCTGTAGCC-3' }\end{array}$ \\
\hline BCS-2 & $\begin{array}{l}\text { F: 5'-CGTGAATGAGCAGACTGAGG-3' } \\
\text { R: 5'-CTGCTTGTTGATCATGTTGTCC-3' }\end{array}$ \\
\hline NCS & $\begin{array}{l}\text { F: 5'-AAGATCTACAGCCAGTGCTTCC-3' } \\
\text { R: 5'-TCCCATCAGTGTCAAAAGTCC-3' }\end{array}$ \\
\hline Ferritin & $\begin{array}{l}\text { F: 5'-AATATCAGACCAAGCGTGGAG-3' } \\
\text { R: 5'-AGCTTCCATTGCCTGAATAGG-3' }\end{array}$ \\
\hline ECR & $\begin{array}{l}\text { F: 5'-GCAAGTTTGGAGGAGACTGC-3' } \\
\text { R: 5'-ACAGCAACATTGGGAGGTTC-3' }\end{array}$ \\
\hline $16 \mathrm{~S}$ & $\begin{array}{l}\text { F: 5'-AAGCTCCTCTAGGGATAACAGC-3' } \\
\text { R: 5'-CGTCTCTTCTAAGCTCCTGCAC-3' }\end{array}$ \\
\hline Actin & $\begin{array}{l}\text { F: 5'-CCATTGTCCGTCTTGATCTTG-3' } \\
\text { R: 5'-AAAGAGTAGCCACGCTCAGTG-3' }\end{array}$ \\
\hline GAPDH & $\begin{array}{l}\text { F: 5'-CACCTGATGTGTCTGTGGTTG-3' } \\
\text { R: 5'-CTTGAGCTTGGCACAGATTTC-3' }\end{array}$ \\
\hline
\end{tabular}

in Calanus finmarchicus. Actin (e.g. ES387224), 16S rRNA (16S; GenBank accession number ES583876), and glyceraldehyde 3-phosphate dehydrogenase (GAPDH; e.g. ES387158) were detected in the SSH libraries but were thought to represent abundant transcripts not fully removed during suppressive PCR; these genes were tested as candidate housekeeping genes. The preliminary screening indicated that GAPDH expression was more variable than both actin and 16S expression (data not shown), so GAPDH was not investigated further.

The remaining 7 genes (ELOV, FABP, RDH, ferritin, $E_{c R}, 16 \mathrm{~S}$ and actin) were quantified in a larger set of samples (originally $\mathrm{n}=21$ shallow, 21 deep; but $\mathrm{n}=20$ shallow, 15 deep after removal of outliers and copepodids with degraded oil sacs). The 4 genes identified by $\mathrm{SSH}$ analysis showed highly significant differences in expression between deep and shallow C5 copepodids (Fig. 3a-d, 2-sample $t$-tests, $\mathrm{p}<0.0001$ ). As expected from the SSH analysis, expression of ELOV, FABP and $\mathrm{RDH}$ was higher in the shallow samples, and expression of ferritin was higher in the deep samples. On average, EcR showed significantly higher expression in the deep samples (Fig. 3e, p = 0.0407); however, there was considerable overlap between the shallow and deep distributions. The housekeeping genes actin and $16 \mathrm{~S}$ did not differ significantly between deep and shallow samples (Fig. $3 f-g$, actin $p=0.2609$, 16S $\mathrm{p}=0.3846)$.

\section{Correlations}

Expression of ELOV, FABP, and RDH were highly correlated with one another (Table 5), and each had a negative relationship with oil sac fractional fullness ( $p$ $<0.002$; Fig. 4). For the copepodids in the shallow sample, both ELOV and FABP had a similar negative relationship with oil sac fractional fullness $(\mathrm{r}=-0.493, \mathrm{p}=$ 0.0271 for ELOV; $r=-0.667, p=0.0013$ for FABP). Expression of ferritin was negatively correlated with ELOV, RDH, and FABP (Table 5), positively correlated with fractional fullness ( $\mathrm{r}=0.753, \mathrm{p}<0.001$, Fig. 4d), and significantly correlated with fractional fullness within both the shallow $(r=0.536, p=0.0149)$ and the

Table 5. Calanus finmarchicus. Correlation matrix of gene expression measured by qPCR. Significance of correlation coefficients: ${ }^{* * *} \mathrm{p}<0.001,{ }^{* *} 0.001 \leq \mathrm{p}<0.01$, no asterisks: $\mathrm{p} \geq 0.05$

\begin{tabular}{|lcclc|}
\hline Gene & FABP & RDH & Ferritin & EcR \\
\hline ELOV & $0.812^{* * *}$ & $0.794^{* * *}$ & $-0.657^{* * *}$ & -0.311 \\
FABP & & $0.686^{* * *}$ & $-0.623^{* * *}$ & -0.176 \\
RDH & & & $-0.519^{* *}$ & -0.106 \\
Ferritin & & & & -0.038 \\
\hline
\end{tabular}



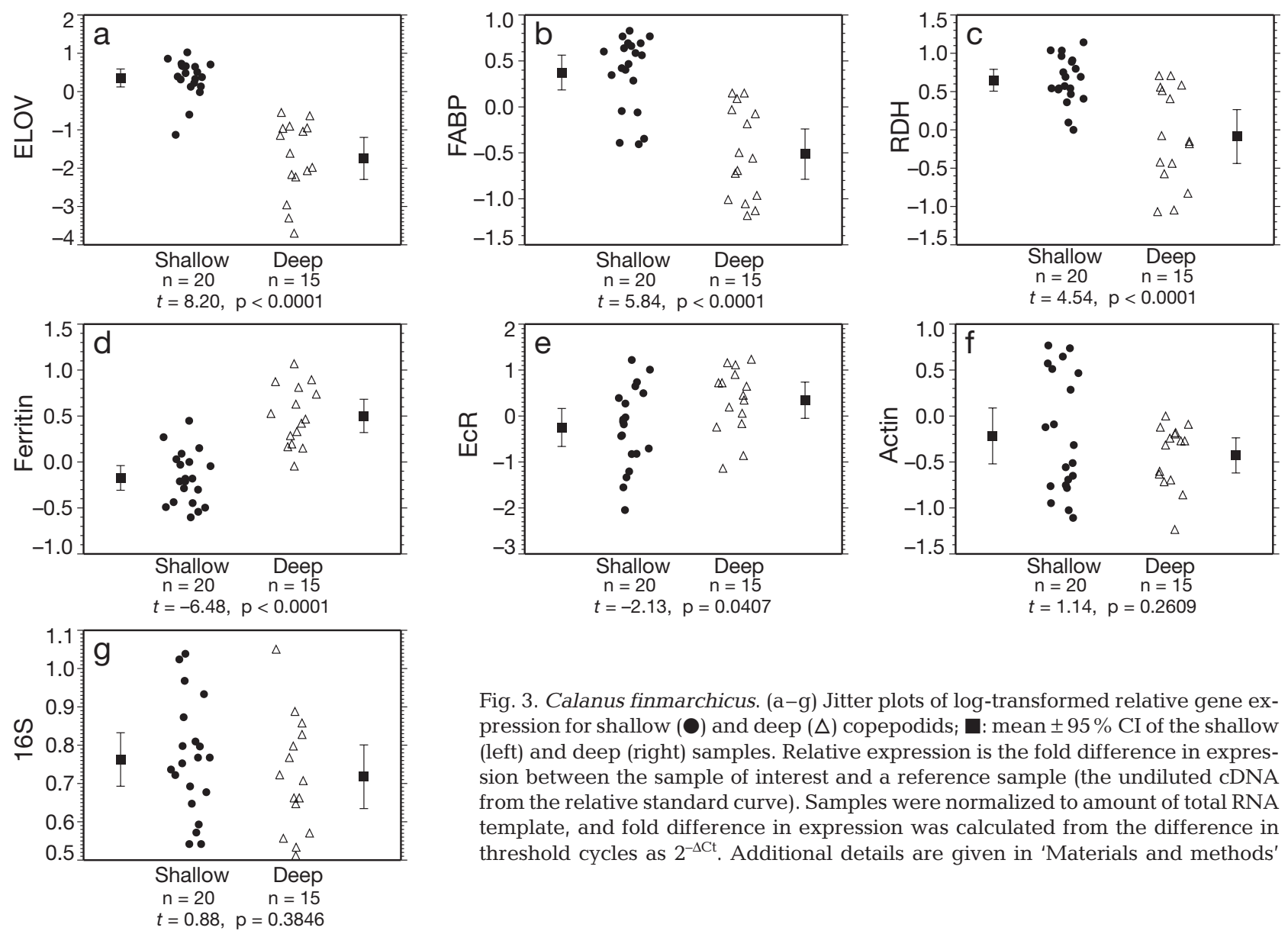

Fig. 3. Calanus finmarchicus. (a-g) Jitter plots of log-transformed relative gene expression for shallow $(\bullet)$ and deep $(\Delta)$ copepodids; $\mathbf{\square}$ : mean $\pm 95 \%$ CI of the shallow (left) and deep (right) samples. Relative expression is the fold difference in expression between the sample of interest and a reference sample (the undiluted cDNA from the relative standard curve). Samples were normalized to amount of total RNA template, and fold difference in expression was calculated from the difference in threshold cycles as $2^{-\Delta \mathrm{Ct}}$. Additional details are given in 'Materials and methods'
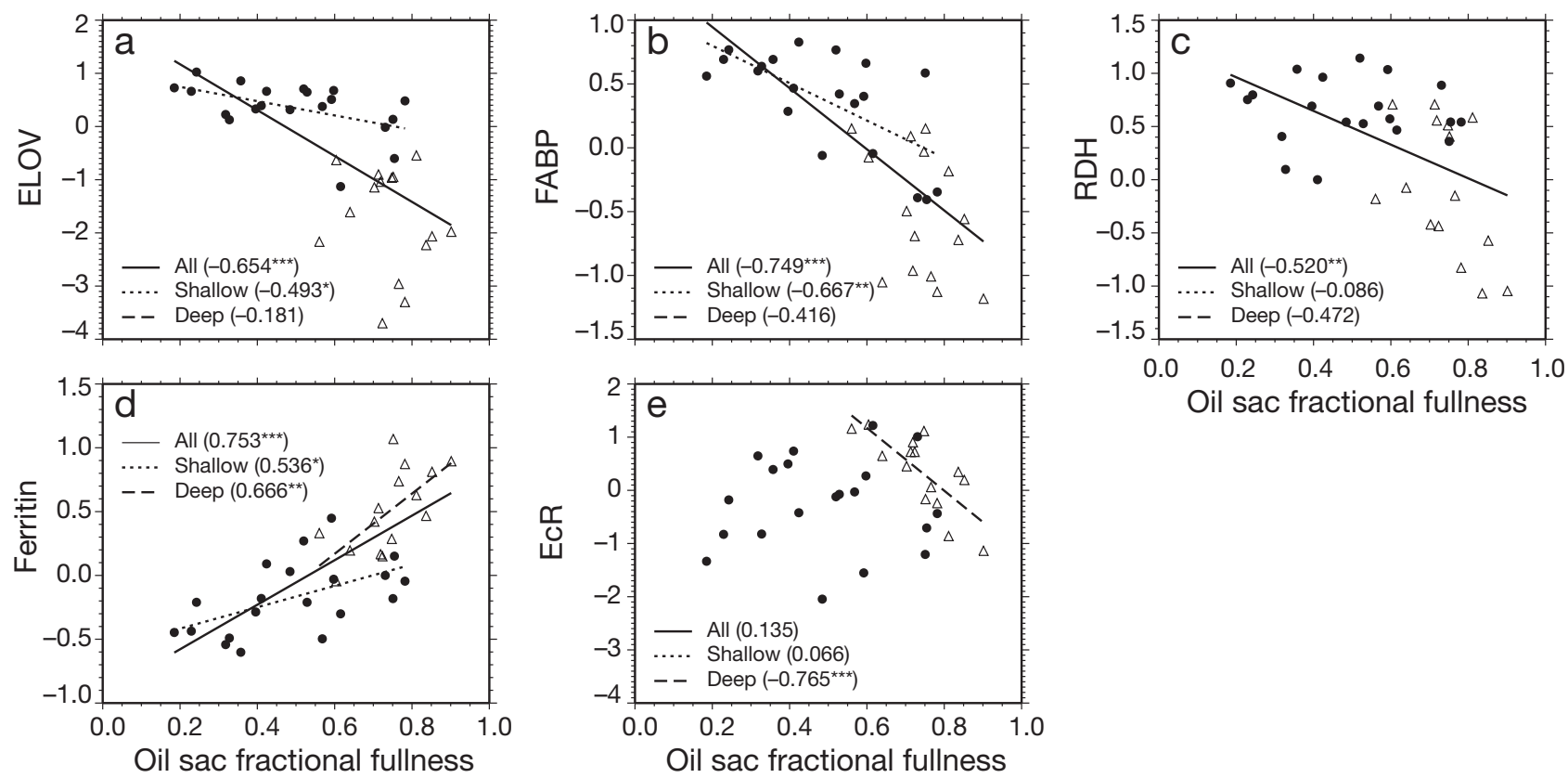

Fig. 4. Calanus finmarchicus. (a-e) Scatterplots of relative gene expression vs. oil sac fractional fullness for shallow $(\bullet)$ and deep $(\Delta)$ copepodids. Parentheses: correlation coefficients; corresponding regression lines shown only if correlation coefficient is significantly different from zero. Significance of correlation coefficients: ${ }^{* *} p<0.001,{ }^{* *} 0.001 \leq p<0.01,{ }^{*} 0.01 \leq p<0.05$, no asterisks: $p \geq 0.05$ 
deep sample $(r=0.666, p=0.0067)$. Expression of EcR was unrelated to fractional fullness for the combined deep and shallow data ( $\mathrm{p}=0.4380)$, but a significant negative correlation existed between EcR and fractional fullness in the deep sample $(\mathrm{r}=-0.765$, $\mathrm{p}=0.0009$ ). The overall correlations between gene expression and fractional fullness primarily indicate the same differences between the shallow and deep samples as detected with the $t$-tests; however, the within-sample correlations likely indicate changes in gene expression associated with either C5 development toward diapause/adulthood (shallow sample) or changes in gene expression associated with the progression of diapause (deep sample).

\section{PCA of gene expression data}

PCA was conducted for the 5 genes of interest (ELOV, FABP, RDH, ferritin, and EcR) using the correlation matrix in Table 5. The 1st principal component accounted for $62 \%$ of the overall variance in the gene expression data, and was strongly influenced by ELOV, FABP, RDH, and ferritin (Fig. 5a). The 2nd principal component accounted for $21 \%$ of the variance, and was dominated by EcR. The shallow and deep samples were strongly differentiated by the 1 st princi- pal component ( 2 sample $t$-test, $t=9.02, \mathrm{p}<0.0001$, Fig. 5b), but not by the 2nd ( $t=-0.62, \mathrm{p}=0.5412)$ or 3rd principal components $(t=1.46, \mathrm{p}=0.1540)$. Shallow samples had higher scores for the 1st principle component, which was indicative of simultaneously higher ELOV, FABP, and RDH expression, and lower ferritin expression. Overall expression of EcR was independent of the other 4 genes (Table 5), hence it alone dominated the 2nd principal component. The 1st principal component was significantly correlated with oil sac fractional fullness for both the deep and shallow samples combined ( $r=-0.760, p<0.0001$; Fig. $5 \mathrm{c}$ ) and for the copepodids in the shallow sample only $(\mathrm{r}=-0.721$, $\mathrm{p}=0.0003$; Fig. 5c), but not for the copepodids in the deep sample $(r=-0.497, p=0.0597$; Fig. 5c). These relationships are consistent with the univariate relationships between gene expression and oil sac fractional fullness (Fig. 4).

\section{DISCUSSION}

\section{Evidence for diapause}

Copepodids from the deep sample were significantly longer than those from the shallow sample, which indicates that these 2 groups developed in different envi-

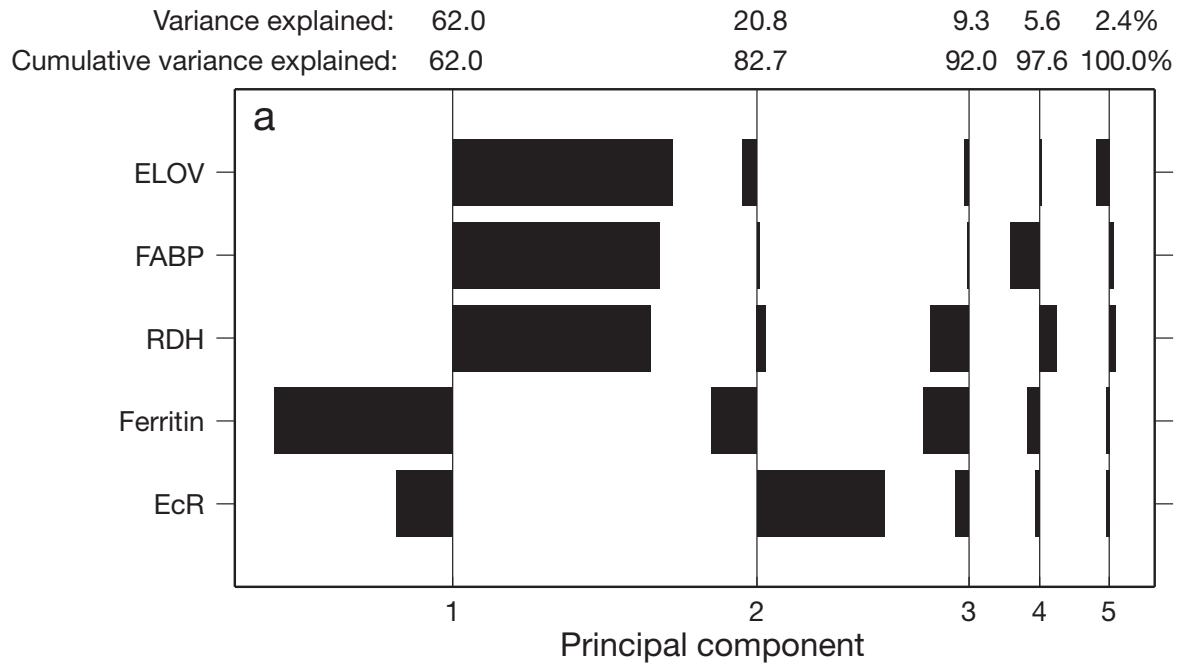

Fig. 5. Calanus finmarchicus. Principal components analysis of relative gene expression data. (a) Eigenvectors showing relative contribution of each gene to each principal component (longer bars: stronger relative contribution). Amount of variance explained by each of the principal components shown above panel. (b) Scatterplot of 1st and 2nd principal component scores for shallow $(\bullet)$ and deep $(\Delta)$ copepodids. (c) Scatterplot of the 1st principal component score and oil sac fractional fullness (as in Fig. 4)
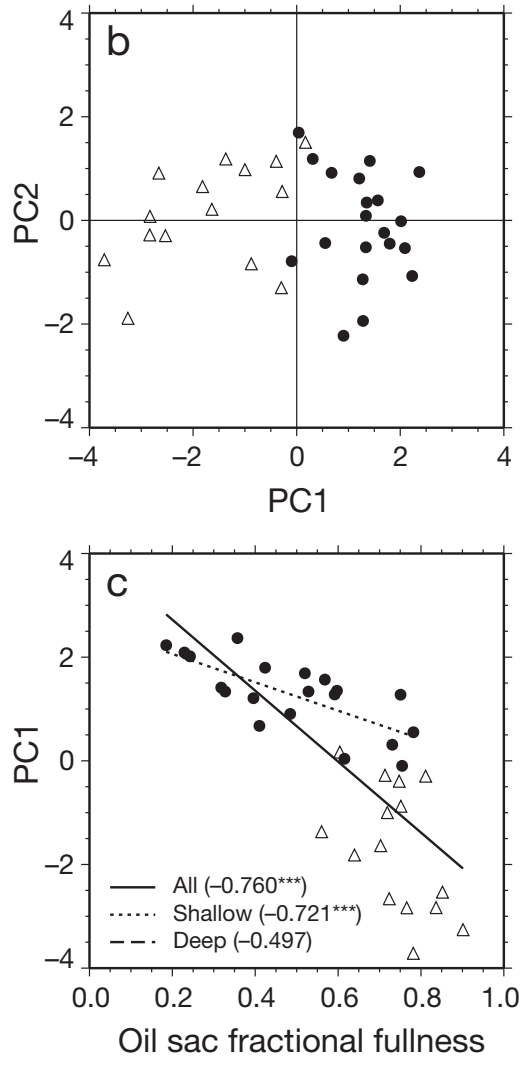
ronmental conditions (Campbell et al. 2001). This observation suggests that the animals in the deep sample were from the first generation (G1) of Calanus finmarchicus spawned in early winter, and the shallow animals were from the second generation (G2) spawned in late winter or early spring (Fig. 1). In situ surface temperatures from NOAA National Data Buoy Center buoy \#44018 located $110 \mathrm{~km}$ to the SW of our sampling station (Fig. 1) were cooler from January to mid-March (the likely development period of G1 copepods) than from mid-March to May (the likely development period of G2 copepods). These observed temperature differences, as well as possible differences in phytoplankton abundance, could account for differences in development rates and prosome lengths (Campbell et al. 2001). The copepodids from the deep sample also had larger oil sacs, lower RNA:DNA, and emptier guts than the shallow copepodids. Both oil sac volume and fractional fullness were significantly correlated with RNA:DNA (volume: $\mathrm{r}=-0.482, \mathrm{p}=0.0171$; fractional fullness: $\mathrm{r}=$ $-0.426, p=0.0377$ ) such that individuals with larger oil sacs tended to have lower RNA:DNA. Low RNA:DNA is indicative of low transcription rates and protein synthesis, and Wagner et al. (1998) found extremely low RNA:DNA in C. finmarchicus collected in the Gulf of Maine in November, a time when the population is presumably in diapause (Fig. 1). The shallow sample contained eggs, nauplii, a wide distribution of all copepodid stages, and adults, which was indicative of a growing population that was actively feeding (indeed, nearly all shallow C5 copepodids had food in their guts). In contrast, the deep sample was dominated by C5 copepodids that were not actively feeding. Our observations of a deep population comprised primarily of G1 C5 copepodids with large oil sacs, low RNA:DNA, and empty guts strongly suggest that the copepodids in the deep sample were in diapause.

The deep sample might also have contained some G2 copepodids, including diapausing animals that had only recently descended from the surface, or active copepodids that were undertaking diel vertical migrations. The former notion is certainly possible, since there is modest overlap in the prosome length distributions from shallow and deep copepodids (Fig. 2a); however, the significant separation in average prosome lengths suggests that most deep copepodids were from the first generation. It is unlikely that diel vertical migrants made up a significant proportion of the deep sample because the deep and surface samples were strongly differentiated in RNA:DNA (Fig. 2e) and none of the deep animals were confirmed to have food in their guts. Our conclusions are in agreement with the timing of C. finmarchicus development in the Gulf of Maine described by Durbin et al. (2000) and Miller et al. (2000).

\section{Evaluation of housekeeping genes}

We compared expression of 3 potential housekeeping genes, GAPDH, actin and 16S. In a preliminary analysis, GAPDH was highly variable and not investigated further. Actin and $16 \mathrm{~S}$ showed more constant expression and did not vary significantly between deep and shallow samples. We did observe a trend toward greater actin expression in shallow samples and would recommend caution in normalizing C. finmarchicus gene expression to actin. During the molt cycle, crustacean muscles undergo cycles of atrophy and remodeling, and actin gene expression can vary by developmental stage and molt phase (Medler et al. 2005, de Oliveira Cesar et al. 2006, Sellars et al. 2007). Given the changes in structure and metabolism associated with diapause and molting, it is not clear that normalization to expression of a single nuclear gene would be appropriate in studies of gene expression associated with diapause state. If housekeeping genes are to be used, ribosomal genes appear most appropriate. This approach (1) assumes that ribosomal and nuclear genes are similarly amplified, (2) requires comparison of highly expressed ribosomal genes with nuclear genes, which are generally expressed at much lower levels, and (3) is only useful if total RNA is used as the starting template.

\section{Gene expression patterns}

We detected robust differences in gene expression between deep and shallow samples. Four of the genes (ELOV, FABP, RDH and ferritin) were identified through SSH analysis of pooled deep and shallow samples. In contrast, EcR was chosen a priori based on the conserved role of ecdysteroids and EcR in regulating life history transitions in arthropods. Collectively, these genes distinguish between deep and shallow C5 copepodids (Fig. 5b). Three other genes (XAD, BCS-2 and $\mathrm{NCS}$ ), identified through $\mathrm{SSH}$, did not show strong differences in expression during the preliminary screening, but with such a small sample size ( $\mathrm{n}=5$ shallow, 5 deep), this screening had low statistical power.

Expression of ELOV, FABP and RDH were all higher in shallow C5 copepodids. In other animals, related genes are essential for lipid synthesis, transport and storage, which are key components of preparation for diapause. ELOV is a member of a family of enzymes that facilitate the regulatory step in fatty acid elongation in both animals and plants (Jakobsson et al. 2006). While the specific role of the cloned Calanus finmarchicus ELOV is currently unknown, some form of elongase is necessary both for the synthesis of juvenoid hormones (Tillman et al. 1999) and for the synthesis of 
storage lipids (wax esters in C. finmarchicus). FABP is related to cytosolic fatty acid binding proteins and retinoid binding proteins. FABPs are involved in cellular transport, utilization, and storage of fatty acids (Söderhäll et al. 2006). FABP family members also bind and transport retinoids with high affinity and help to regulate the amount of ligand available to retinoid receptors (Zimmerman \& Veerkamp 2002). In C. finmarchicus, FABP most likely functions to facilitate the transport of wax esters into the oil sac; FABP may also store and transport lipophilic hormones, such as retinoids. RDH is most similar to insect genes in the NAD(P)-dependent 'short chain' dehydrogenase/ reductase (SDR) family. SDR enzymes include over 3000 annotated sequences with specificities toward diverse substrates including steroids, retinoids, prostaglandins, alcohols, sugars and aromatic compounds (Filling et al. 2002, Persson et al. 2003). In the synthesis of wax esters, NAD(P)-dependent dehydrogenases catalyze the conversion of fatty alcohols and aldehydes to fatty acids (Ishige et al. 2002). Other SDR family members act predominantly as reductases, catalyzing the conversion of fatty acids to aldehydes and alcohols. The substrate for the cloned RDH is unknown, and future experiments will be needed to determine whether it plays a role in the synthesis of storage lipids or hormones, lipid catabolism, xenobiotic metabolism, or other functions.

Expression of ferritin was higher in deep C5 copepodids than in shallow copepodids. Ferritin is an ironbinding protein that is highly expressed in encysted embryos of the brine shrimp Artemia franciscana (Chen et al. 2003). In Artemia, ferritin and a related protein, artemin, have been hypothesized to chelate iron stores (i.e. sequester iron through coordinate bonding to the protein, which may slow development), act as chaperone proteins, protect against oxidative stress, and/or maintain cellular hydration (Chen et al. 2003). High ferritin expression in diapausing copepods may help to delay development and/or protect proteins and other cellular components from oxidation and degradation.

On average, expression of EcR was higher in the deep C5 copepodids than in the shallow copepodids. In crustaceans and other molting animals, ecdysteroids regulate molting, reproduction and development (Chang 1985, Subramoniam 2000, Riddiford et al. 2003). Ecdysteroids act by binding to and activating the EcR, a member of the nuclear receptor superfamily of transcription factors (Koelle et al. 1991). Activated EcR forms a dimer with the retinoid X receptor (RXR, called ultraspiracle in insects) and binds to specific response elements on the DNA to regulate transcription of target genes (Yao et al. 1993, Hu et al. 2003). In decapod crustaceans, ecdysteroid levels generally peak during the premolt phase, during which the old exoskeleton is degraded and a new exoskeleton is secreted in preparation for molting (Chang 1985, Yodmuang et al. 2004). Similarly, in lab-reared Calanus pacificus C5 copepodids, ecdysteroid levels peaked during the transition to premolt (Johnson 2003). EcR expression has not previously been measured in copepods, but expression of EcR does increase during premolt in fiddler crab claw muscle (Chung et al. 1998). One might predict that in the present study, ecdysteroid levels would be variable but higher in the surface individuals, as some copepodids progress toward premolt and ultimately adulthood; however, this pattern was not observed in EcR expression. The EcR expression pattern is difficult to interpret without knowing the molt stage of the copepodids or the relationship of C. finmarchicus EcR expression to molt phase and/or ecdysteroid concentration. Given our relatively small sample size, it is possible that we missed an ephemeral peak in EcR expression, comparable to the premolt peak in ecdysteroid concentration. On the other hand, ecdysteroid synthesis and EcR expression can decrease following exposure to ecdysteroids through negative feedback loops (Beydon \& Lafont 1983, Sakurai \& Williams 1989, Dell et al. 1999, Kim et al. 2005). Future study is needed to characterize EcR expression patterns in a synchronous population of known molt phase.

As described above, gene expression varied significantly between deep and shallow samples, allowing for strong differentiation of the 2 groups by the 1 st principle component. Even with a relatively small sample size, some additional variability in gene expression within the deep and shallow samples was correlated with morphological measurements. ELOV, FABP, and RDH were all negatively correlated with oil sac fractional fullness (Fig. $4 \mathrm{a}-\mathrm{c}$ ). The shallow samples had higher expression of ELOV and FABP in animals with the smallest oil sacs. This observation is consistent with the need for newly molted animals to synthesize large amounts of wax esters in preparation for diapause. Ferritin was positively correlated with oil sac fractional fullness in both deep and shallow samples (Fig. 4d). Chelation of metals (particularly iron, but possibly other metals) by ferritin may help to delay development as animals transition into diapause and protect cells from oxidative damage during diapause. In deep copepodids, EcR expression was highest in animals with the smallest oil sacs (Fig. 4e). While the EcR expression patterns require additional investigation, higher EcR expression in animals with smaller oil sacs may indicate preparation for emergence from diapause and entry into premolt.

An integrative and speculative interpretation of the observed gene expression patterns is shown in Fig. 6 . 


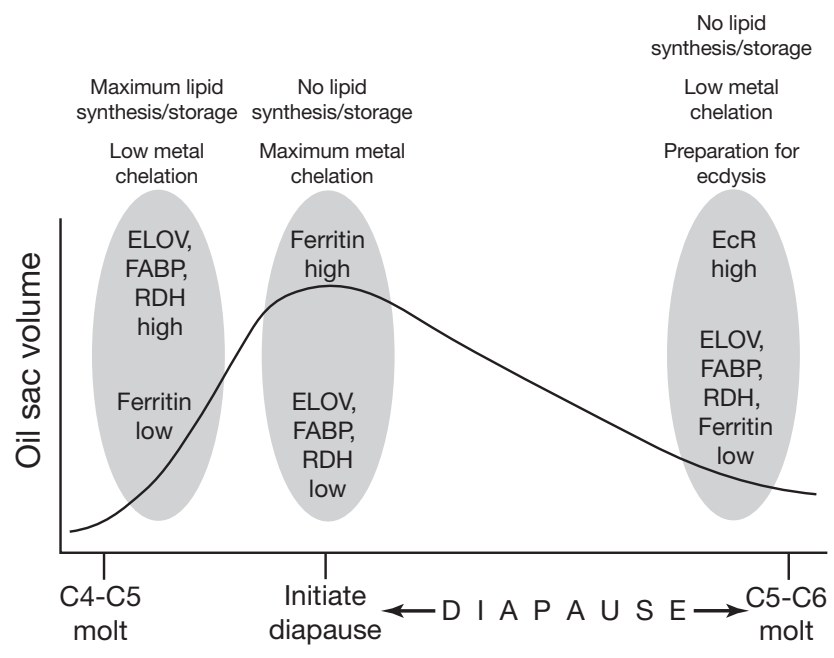

Fig. 6. Calanus finmarchicus. Hypothesized progression of oil sac volume (line) and gene expression (in grey ovals) through the penultimate molt, initiation of diapause, diapause, and the terminal molt. Speculative physiological states based on gene expression data are shown above the figure indicating lipid synthesis/storage (ELOV, FABP, RDH), chelation of metals and protection of cells from oxidative damage (ferritin), and preparation for ecdysis (EcR)

Newly molted C5 copepodids have high rates of lipid synthesis and storage and small oil sacs, represented by high expression of ELOV, FABP and RDH and low expression of ferritin. As copepodids prepare for and enter into diapause, lipid synthesis and storage slow (low ELOV, FABP and RDH), and ferritin increases to delay development and protect cells from oxidative damage. As ferritin expression decreases during diapause, metals may become more available to facilitate resumption of development. Finally, and perhaps most speculatively, EcR expression increases as copepodids prepare to emerge from diapause. Testing this hypothesized developmental pathway will require a more rigorous characterization of the history and status of individual copepods. Future studies should measure temporal changes in gene expression as a synchronous (laboratory) population progresses through the fifth copepodid stage, accumulates storage lipids, and prepares for ecdysis.

In conclusion, morphological and biochemical criteria indicated that the deep and shallow Calanus finmarchicus C5 copepodids we sampled represented diapausing and active populations. We identified 5 genes that were differentially expressed between the 2 groups and correlated gene expression with morphological measurements related to lipid storage. Changes in gene expression are consistent with high lipid synthesis rates during preparation for diapause and chelation of metals during diapause. The changes in gene expression described in this study are most likely downstream from the key regulators of diapause behavior, but they serve as indicators of physiological condition and provide a foundation for studies of the mechanisms that regulate diapause in oceanic copepods.

Acknowledgements. We thank J. Stegeman, P. Wiebe, C. Ashjian, and M. Hahn for providing facilities, equipment and advice, A. Aruda for assistance with the laboratory analyses, N. Lysiak, M. Patrician, C. Tremblay, and I. Biedron for tireless assistance in the field, and the officers and crew of the NOAA Ship 'Albatross IV' as well as chief scientist F. Wenzel of the Northeast Fisheries Science Center's Protected Species Branch for support at sea. We are grateful to R. Henderson for sharing his unpublished data, and 3 anonymous reviewers for their thoughtful criticisms. The DIALOG program, organized by S. Weiler, provided an initial opportunity to develop our ideas for this project. Funding was provided by the WHOI Ocean Life Institute and the John E. and Anne W. Sawyer Fund.

\section{LITERATURE CITED}

Basedow SL, Tande KS (2006) Cannibalism by female Calanus finmarchicus on naupliar stages. Mar Ecol Prog Ser 327: 247-255

Beydon P, Lafont R (1983) Feedback inhibition of ecdysone production by 20-hydroxyecdysone in Pieris brassicae pupae. J Insect Physiol 29:529-533

Bonnet D, Harris R, Hay S, Ingvarsdittir A, Simon O (2007) Histological changes of the digestive epithelium in Calanus finmarchicus: an index for diapause. Mar Biol 151:313-326

- Burgoyne RD (2004) The neuronal calcium-sensor proteins. Biochim Biophys Acta 1742:59-68

Campbell RG, Wagner MM, Teegarden GJ, Boudreau CA, Durbin EG (2001) Growth and development rates of the copepod Calanus finmarchicus reared in the laboratory. Mar Ecol Prog Ser 221:161-183

Chang E (1985) Hormonal control of molting in decapod crustacea. Am Zool 25:179-185

Chen T, Amons R, Clegg J, Warner A, MacRae T (2003) Molecular characterization of artemin and ferritin from Artemia franciscana. Eur J Biochem 270:137-145

Chung ACK, Durica DS, Hopkins PM (1998) Tissue-specific patterns and steady-state concentrations of ecdysteroid receptor and retinoid-X-receptor mRNA during the molt cycle of the fiddler crab, Uca pugilator. Gen Comp Endocrinol 109:375-389

Crawford DL (1995) Nuclear genes from the copepod Calanus finmarchicus. Mol Mar Biol Biotechnol 4:241-247

Dale T, Bagøien E, Melle W, Kaartvedt S (1999) Can predator avoidance explain varying overwintering depth of Calanus in different oceanic water masses? Mar Ecol Prog Ser 179:113-121

Dell S, Sedlmeier D, Bocking D, Dauphin-Villemont C (1999) Ecdysteroid biosynthesis in crayfish Y-organs: feedback regulation by circulating ecdysteroids. Arch Insect Biochem Physiol 41:148-155

Denlinger D (2002) Regulation of diapause. Annu Rev Entomol 47:93-122

de Oliveira Cesar J, Zhao B, Malecha S, Ako H, Yang J (2006) Morphological and biochemical changes in the muscle of the marine shrimp Litopenaeus vannamei during the molt cycle. Aquaculture 261:688-694 
Durbin EG, Runge JA, Campbell RG, Garrahan PR, Casas MC, Plourde S (1997) Late fall-early winter recruitment of Calanus finmarchicus on Georges Bank. Mar Ecol Prog Ser 151: 103-114

Durbin EG, Garrahan PR, Casas MC (2000) Abundance and distribution of Calanus finmarchicus on the Georges Bank during 1995 and 1996. ICES J Mar Sci 57: 1664-1685

> Filby AL, Tyler CR (2007) Appropriate 'housekeeping' genes for use in expression profiling the effects of environmental estrogens in fish. BMC Mol Biol 8:10

Filling C, Berndt K, Benach J, Knapp S and others (2002) Critical residues for structure and catalysis in short-chain dehydrogenases/reductases. J Biol Chem 277:25677-25684

Flannagan $\mathrm{R}$, Tammariello S, Joplin $\mathrm{K}$, Cikra-Ireland $\mathrm{R}$, Yocum G, Denlinger D (1998) Diapause-specific gene expression in pupae of the flesh fly Sarcophaga crassipalpis. Proc Natl Acad Sci USA 95:5610-5620

Hallberg E, Hirche HJ (1980) Differentiation of mid-gut in adults and over-wintering copepodids of Calanus finmarchicus (Gunnerus) and C. helgolandicus Claus. J Exp Mar Biol Ecol 48:283-295

Hayward S, Pavlides S, Tammariello S, Rinehart J, Denlinger D (2005) Temporal expression patterns of diapause-associated genes in flesh fly pupae from the onset of diapause through post-diapause quiescence. J Insect Physiol 51: 631-640

Heath M, Boyle P, Gislason A, Gurney W and others (2004) Comparative ecology of over-wintering Calanus finmarchicus in the northern North Atlantic, and implications for life-cycle patterns. ICES J Mar Sci 61:698-708

- Hirche HJ (1983) Overwintering of Calanus finmarchicus and Calanus helgolandicus. Mar Ecol Prog Ser 11:281-290

Hirche HJ (1989) Spatial distribution of digestive enzyme activities of Calanus finmarchicus and C. hyperboreus in Fram Strait/Greenland Sea. J Plankton Res 11:431-443

Hirche HJ (1996) Diapause in the marine copepod, Calanus finmarchicus: a review. Ophelia 44:129-143

Hu X, Cherbas L, Cherbas P (2003) Transcription activation by the ecdysone receptor (EcR/USP): identification of activation functions. Mol Endocrinol 17:716-731

Ishige T, Tani A, Takabe K, Kawasaki K, Sakai Y, Nobuo K (2002) Wax ester production from n-alkanes by Acinetobacter sp. strain M-1: ultrastructure of cellular inclusions and role of acyl coenzyme A reductase. Appl Environ Microbiol 68:1192-1195

Jakobsson A, Westerberg R, Jacobsson A (2006) Fatty acid elongases in mammals: their regulation and roles in metabolism. Prog Lipid Res 45:237-249

Johnson CL (2003) Ecdysteroids in the oceanic copepod Calanus pacificus: variation during molt cycle and change associated with diapause. Mar Ecol Prog Ser 257: 159-165

Johnson C (2004) Seasonal variation in the molt status of an oceanic copepod. Prog Oceanogr 62:15-32

Kim HW, Chang E, Mykles D (2005) Three calpains and ecdysone receptor in the land crab Gecarcinus lateralis: sequences, expression and effects of elevated ecdysteroid induced by eyestalk ablation. J Exp Biol 208:3177-3197

Koelle MR, Talbot WS, Segraves WA, Bender MT, Cherbas P, Hogness DS (1991) The Drosophila EcR gene encodes an ecdysone receptor, a new member of the steroid receptor superfamily. Cell 67:59-77

Lee RF, Hagen W, Kattner G (2006) Lipid storage in marine zooplankton. Mar Ecol Prog Ser 307:273-306

- Liu T, Zimmerman K, Patterson G (2004) Regulation of signaling genes by TGFbeta during entry into dauer diapause in
C. elegans. BMC Dev Biol 4:11

Medler S, Brown K, Chang E, Mykles D (2005) Eyestalk ablation has little effect on actin and myosin heavy chain gene expression in adult lobster skeletal muscles. Biol Bull 208: $127-137$

Meise C, O'Reilly J (1996) Spatial and seasonal patterns in abundance and age-composition of Calanus finmarchicus in the Gulf of Maine and on Georges Bank: 1977-1987. Deep-Sea Res 43:1473-1501

Miller CB, Nelson DM, Weiss C, Soeldner AH (1990) Morphogenesis of opal teeth in calanoid copepods. Mar Biol 106:91-101

Miller CB, Cowles TJ, Wiebe PH, Copley NJ, Grigg H (1991) Phenology in Calanus finmarchicus; hypotheses about control mechanisms. Mar Ecol Prog Ser 72:79-91

Miller CB, Morgan CA, Prahl FG, Sparrow MA (1998) Storage lipids of the copepod Calanus finmarchicus from Georges Bank and the Gulf of Maine. Limnol Oceanogr 43:488-497

Miller CB, Crain JA, Morgan CA (2000) Oil storage variability in Calanus finmarchicus. ICES J Mar Sci 57:1786-1799

Ohman M, Runge J (1994) Sustained fecundity when phytoplankton resources are in short supply: Omnivory by Calanus finmarchicus in the Gulf of St. Lawrence. Limnol Oceanogr 39:21-36

Okazaki Y, Shizuri Y (2000) Structures of six cDNAs expressed specifically at cypris larvae of barnacles, Balanus amphitrite. Gene 250:127-135

Persson B, Kallberg Y, Oppermann U, Jörnvall H (2003) Coenzyme-based functional assignments of short-chain dehydrogenases/reductases (SDRs). Chem Biol Interact 143-144:271-278

Riddiford LM, Hiruma K, Zhou X, Nelson CA (2003) Insights into the molecular basis of the hormonal control of molting and metamorphosis from Manduca sexta and Drosophila melanogaster. Insect Biochem Mol Biol 33:1327-1338

Sakurai S, Williams C (1989) Short-loop negative and positive feedback on ecdysone secretion by prothoracic gland in the tobacco hornworm, Manduca sexta. Gen Comp Endocrinol 75:204-216

Sameoto DD, Herman AW (1990) Life cycle and distribution of Calanus finmarchicus in deep basins on the Nova Scotia shelf and seasonal changes in Calanus spp. Mar Ecol Prog Ser 66:225-237

Sellars MJ, Vuocolo T, Leeton LA, Coman GJ, Degnan BM, Preston NP (2007) Real-time RT-PCR quantification of Kuruma shrimp transcripts: a comparison of relative and absolute quantification procedures. J Biotechnol 129: 391-399

Söderhäll I, Tangprasittipap A, Liu H, Sritunyalucksana K, Prasertasan P, Jiravanichpaisal P, Söderhäll K (2006) Characterization of a hemocyte intracellular fatty acidbinding protein from crayfish (Pacifastacus leniusculus) and shrimp (Penaeus monodon). FEBS J 273:2902-2912

Subramoniam T (2000) Crustacean ecdysteroids in reproduction and embryogenesis. Comp Biochem Physiol C 125: 135-156

Tachibana S, Numata H, Goto S (2005) Gene expression of heat-shock proteins (Hsp23, Hsp70, Hsp90) during and after larval diapause in the blow fly Lucilia sericata. J Insect Physiol 51:641-647

Tande KS, Slagstad D (1982) Ecological investigation on the zooplankton community of Balsfjorden, northern Norway: seasonal and short-time variations in enzyme activity in copepodite stage V and stage VI males and females of Calanus finmarchicus (Gunnerus). Sarsia 67:63-68

Tillman JA, Seybold SJ, Jurenka RA, Blomquist GJ (1999) Insect pheromones: an overview of biosynthesis and 
endocrine regulation. Insect Biochem Mol Biol 29: 481-514

Tricarico C, Pinzani P, Bianchi S, Paglierani M and others (2002) Quantitative real-time reverse transcription polymerase chain reaction: normalization to rRNA or single housekeeping genes is inappropriate for human tissue biopsies. Anal Biochem 309:293-300

Tsuda A, Miller C (1998) Mate-finding behaviour in Calanus marshallae Frost. Phil Trans R Soc Lond Ser B 353:713-721

Wagner M, Durbin E, Buckley L (1998) RNA:DNA ratios as indicators of nutritional condition in the copepod Calanus finmarchicus. Mar Ecol Prog Ser 162:173-181

Wagner MM, Campbell RG, Boudreau CA, Durbin EG (2001) Nucleic acids and growth of Calanus finmarchicus in the laboratory under different food and temperature conditions. Mar Ecol Prog Ser 221:185-197

Wang J, Kim S (2003) Global analysis of dauer gene expression in Caenorhabditis elegans. Development 130:1621-1634

Wiebe P, Burt K, Boyd S, Morton A (1976) A multiple opening/closing net and environmental sensing system for sampling zooplankton. J Mar Res 34:313-326

Wiebe P, Beardsley R, Bucklin A, Mountain D (2001) Coupled biological and physical studies of plankton populations in the Georges Bank region and related North Atlantic

Editorial responsibility: Kenneth Sherman,

Narragansett, Rhode Island, USA
GLOBEC study sites. Deep-Sea Res II 48:1-2

Williams KD, Busto M, Suster ML, So AKC, Ben-Shahar Y, Leevers SJ, Sokolowski MB (2006) Natural variation in Drosophila melanogaster diapause due to the insulinregulated P13-kinase. Proc Natl Acad Sci USA 103:15911-15915

Yao TP, Forman BM, Jiang Z, Cherbas L and others (1993) Functional ecdysone receptor is the product of $E C R$ and Ultraspiracle genes. Nature 366:476-479

Yebra L, Hirst A, Hernandez-Leon S (2006) Assessment of Calanus finmarchicus growth and dormancy using the aminoacyl-tRNA synthetases (AARS) method. J Plankton Res 28:1191-1198

Yodmuang S, Udomkit A, Treerattrakool S, Panyim S (2004) Molecular and biological characterization of molt-inhibiting hormone of Penaeus monodon. J Exp Mar Biol Ecol 312: 101-114

Zimmerman AW, Veerkamp JH (2002) New insights into the structure and function of fatty acid-binding proteins. Cell Mol Life Sci 59:1096-1116

Zylka MJ, Reppert SM (1999) Discovery of a putative hemebinding protein family (SOUL/HBP) by two-tissue suppression subtractive hybridization and database searches. Brain Res Mol Brain Res 74:175-181

Submitted: April 29, 2007; Accepted: August 7, 2007

Proofs received from author(s): January 30, 2008 